\title{
Past, present and future of the telecommunications industry
}

Citation for published version (APA):

Pennings, J. S. J., van Kranenburg, H. L., \& Hagedoorn, J. (2005). Past, present and future of the telecommunications industry. METEOR, Maastricht University School of Business and Economics. METEOR Research Memorandum No. 016 https://doi.org/10.26481/umamet.2005016

Document status and date:

Published: 01/01/2005

DOI:

10.26481/umamet.2005016

Document Version:

Publisher's PDF, also known as Version of record

\section{Please check the document version of this publication:}

- A submitted manuscript is the version of the article upon submission and before peer-review. There can be important differences between the submitted version and the official published version of record.

People interested in the research are advised to contact the author for the final version of the publication, or visit the DOI to the publisher's website.

- The final author version and the galley proof are versions of the publication after peer review.

- The final published version features the final layout of the paper including the volume, issue and page numbers.

Link to publication

\footnotetext{
General rights rights.

- You may freely distribute the URL identifying the publication in the public portal. please follow below link for the End User Agreement:

www.umlib.nl/taverne-license

Take down policy

If you believe that this document breaches copyright please contact us at:

repository@maastrichtuniversity.nl

providing details and we will investigate your claim.
}

Copyright and moral rights for the publications made accessible in the public portal are retained by the authors and/or other copyright owners and it is a condition of accessing publications that users recognise and abide by the legal requirements associated with these

- Users may download and print one copy of any publication from the public portal for the purpose of private study or research.

- You may not further distribute the material or use it for any profit-making activity or commercial gain

If the publication is distributed under the terms of Article $25 \mathrm{fa}$ of the Dutch Copyright Act, indicated by the "Taverne" license above, 


\title{
Past, Present and Future of the Telecommunications Industry
}

\author{
Jacqueline Pennings \\ Hans van Kranenburg \\ John Hagedoorn \\ Maastricht University \\ Faculty of Economics and Business Administration \\ Department of Organization and Strategy \\ P.O. Box 616 \\ 6200 MD Maastricht \\ The Netherlands \\ Phone: +31 (0) 433883823 \\ Fax: +31 (0) 433884893 \\ E-mail: J.pennings@ os.unimaas.nl \\ H.vankranenburg@os.unimaas.nl \\ J.hagedoorn@os.unimaas.nl
}

20 May 2005

Chapter in the book: The Aging New Economy: The Growth and Dynamics of New Media Firms. Editor: Cinzia Dalzotto (2005) forthcoming. 


\section{$1 \quad$ Introduction}

The telecommunications industry has made its mark in history. It has experienced a series of dramatic changes since its inception in the 1880s. After a flourishing start, wide-ranging in form and structure, the telecommunications industry developed gradually into a public-owned industry without competition. Moreover, during the first half of the $20^{\text {th }}$ century, the telecommunications industry became a relative stable industry worldwide. Nonetheless, in the 1950s, thoughts of deregulating the telecommunications industry started to develop gradually. The United States of America (USA) were the first country to deregulate the telecommunications market. Following, other countries also started to deregulate their telecommunications markets. In the past three decades, due to the latest liberalization and privatization wave in the world, the telecommunications industry has turned into a dynamic environment and is rapidly growing (Graack, 1996). In addition, the New Economy emerged and brought new technological developments in the 1990s. For the telecommunications companies, these developments created new opportunities, but also threats. They have stimulated the convergence of previously distinct industries such as the telecommunications, information technology, entertainment, media, and consumer electronics into a new industry, the so-called multimedia information industry (Chan-Olmsted \& Jamison, 2001).

In this rapidly changing industry, the availability of state-of-the art technological know-how, innovations and domestic and international market access are critical to a company's competitive success. As a result of a number of radical political and technological developments, telecommunications companies needed new or complementary capabilities and resources to fulfill the new demands and requirements. Therefore, extensive use was made of alliances, mergers and acquisitions (M\&As) (Chan-Olmsted \& Jamison, 2001; Waverman \& Trillas, 2002). Companies had to reconsider their strategies and their product and market portfolio. This is probably one of the main reasons why the strategic behavior of telecommunications companies has attracted so much attention in recent years, both in the 
academic literature and in the popular press. Against this unique historical background, we provide an analysis that gives insight into the most important historical events and their impact on the telecommunications industry since the innovation of the telephone in the 1880s. The analysis is confined to the strategic behavior of telecommunications companies in order to deal with internationalization, economies of scale, competition, and recent needs of the consumers for an integrated product (Chan-Olmsted \& Jamison, 2001). The paper discusses inter-firm partnerships and acquisition patterns, because these integrative modes have frequently been used by the telecommunications companies, especially to enter into the New Economy industries. These integrative modes were used to gain access to new capabilities, resources and markets. Telecommunications companies needed to develop or acquire specific technological capabilities and resources to deal with the rapidly changing environment. These companies allied with and acquired new companies, in particular, young innovative companies from the New Economy with a distinctive technology (Li \& Whalley, 2002; Stubbs, 2004). The integrative modes were also used to enter new markets (Jamison, 1998).

This study is structured as follows. Sections 2 and 3 describe the early development of the telecommunications industry. Section 4 discusses the deregulation actions in the world and their implications on the telecommunications industry in the second half of the $20^{\text {th }}$ century. This is followed by a discussion of the technological developments in the industry and the emergence of the multimedia information industry. Although the innovations are numerous, the attention is restricted to the general impact of the technological development on the industry. Section 6 describes the general trends of companies' strategic actions to adjust to the new demands and requirements. It presents a historical distribution of partnerships and acquisitions with special reference to internationalization and industries. Some conclusions to be drawn from this study are discussed in the last section. An important finding is that, next to the increase in M\&A and alliance activities, the New Economy 
industries have developed tremendously. These developments created opportunities for telecommunications firms to access new markets and enter into each others business.

\section{The Impact of the Telephone Technology}

In 1884, Alexander Graham Bell invented the first telephone. This innovation introduced a complete new way of communication. It made communication more efficient and faster. The innovation altered not only the types of communications services available, but also the industry's cost structure and the degree of substitutability and complementarities of services and products. Before the telephone could be put in use, however, an extensive infrastructure had to be constructed and the technology had to be made more robust to handle long-distance calls (Casson, 1971; Wallsten, 2001a). These conditions required huge and risky investments. As a consequence, these investments were carried out by the government. The government of the USA was the first to adopt and implement the telephony technology next to the telegraph system. Because of privately owned telegraph system in the U.S., the government was less obligated to protect this industry (Wallsten, 2001a). The policy of the U.S. was to stimulate fair market competition. The competition in the USA increased when the Bell patents expired in 1894. Due to these developments the U.S. showed the highest telephone penetration at that time (Wallsten, 2001a). However, other countries were reluctant to accept the new communications system. Their governments rather wished to remain with the telegraph services, since this was a state monopoly that provided power and high pay-offs. When telephone technology became legitimate, the governments, particularly in Europe, were also forced to incorporate the new communications technology within their system. Some governments introduced the technology in their own control and the use of the telephone under strict measures, while others let private companies take their chances. In Germany, for example, the public was not allowed to lend their telephone to the neighbors. If they did, they 
risked a punishment of six months in jail (Casson, 1971). In other countries, such as those in Scandinavia, a more liberal approach was taken.

Throughout the world, three industrial structures emerged within the industry at the end of the $19^{\text {th }}$ century and the beginning of the $20^{\text {th }}$ century. The first group of countries allowed competition amongst private companies. For instance, the government of Denmark did not wish to enter into the telephony business. Thus, only private companies operated in the market. The only area where the government did participate in was the construction of long distance lines (Wallsten, 2001a). In the USA, the industry started with two competitors, fiercely competing over customers. Western Union had the advantage of being a national established prestigious company, it owned a wire infrastructure all over the country, and had the unique right of building wires along roads and on top of houses (Casson, 1971). The Bell Company, on the other hand, had the advantage of owning the Bell patents.

The second group showed a significant overlap with the first group but included a state-owned company that was competing with the private companies. Norway, Sweden and Finland were the best examples of this scenario (Andersson-Skog, 2000). These first two groups were characterized by significant competition within the countries. The third group of countries only allowed a state-owned company that had a monopoly position (Wallsten, 2001a). In general, countries from the third group were hesitant to invest in infrastructure, therewith hampering the development of the industry. This structure was preferred in continental Europe. For instance, France operated a monopoly structure of the telecommunications industry since 1889. At that time, it was lagging behind in telephone connections. In 1914, France had invested in 0.8 telephones per hundred inhabitants compared to 4.5 telephones in Denmark (Wallsten, 2001a).

As mentioned above, in the early stage of the industry, two significant differences could be observed between countries with on the one hand, only state-owned telecommunications companies and on the other hand, countries with free competition in the 
telecommunications market. Countries allowing for competition had a higher telephone penetration then countries that had a state-owned monopoly in telecommunications. Contrary to general expectations, some countries with competition among telecommunications companies even had higher telephone penetration in rural areas than countries with stateowned telecommunications companies (Wallsten, 2001a). With regards to pricing for longdistance service, the countries with competition charged lower prices for telephone services then countries with state-owned monopolies (Wallsten, 2001a).

\section{Trend towards a Monopolistic Market Structure}

Mixed competition structures were present in the first development stage of the industry. After a successful start, the telecommunications industry developed gradually into a stateowned industry without competition. The reason for this development was that private telecommunications companies concentrated their activities on the profitable areas. They only built sophisticated network infrastructures in the high population-density areas (Casson, 1971; Thimm, 1992). The focus and strategy of the companies created an increasing gap between the regions. Because a sophisticated communications system stimulated the economic and social activities in a region, it was important to have an up-to-date network for the whole country. Without a solid and innovative infrastructure, the country could not reach the optimal welfare level (Chandler, 2001). Due to these developments governments felt the increased need to take up responsibility and control the telecommunications industry. In the second half of the industrial revolution, the telecommunications industry turned into a government-owned business ${ }^{1}$. The monopolization of the industry was a global trend. The monopolist was now solely responsible for the technological and economic environment, introducing new technologies and coping with changing markets (Chandler, 2001). In this period, the national telecommunication markets were characterized by stable growth. The

\footnotetext{
${ }^{1}$ This was a logical step because all utilities, like electricity and water, and train services were governmentowned at that time.
} 
only regulatory framework was the government. This situation continued through the mid $20^{\text {th }}$ century.

The 1950s signaled a change in the governments' perception of the proper telecommunications structure. Particularly, the government of the USA wanted to allow competition in its telecommunications market. At that time, American Telephone and Telegraph (AT\&T) and its Bell System Operating Companies had a monopoly position in the USA. It was created after the establishment of the Communications Act of 1934 (Chakravarthy, 1991). In 1968, the Federal Communications Commission's (FCC) 890 Ruling allowed one fixed-lines competitor into the market (Kennedy, 1989). In 1969, the USA introduced a competitor to its monopolist AT\&T. The first competitor that was allowed to enter the market was Microwave Communications International (MCI) (Chakravarthy, 1991). It was only allowed to enter the fixed-lines business between two cities. AT\&T stayed the key provider of fixed-line services. Hence, the FCC had imposed regulations to the industry players in order to advance equal competition, like asymmetric price regulation and access charges (Green \& Teece, 1998).

During the period when a deregulated telecommunications market was created, the USA was invaded by many non-USA equipment vendors. In reaction, other countries were urged to open their markets in line with the USA model (Thimm, 1992). The USA government threatened with trade reciprocity (Snow, 1995). The reformation of the United States telecommunications industry triggered open competition and the establishment of independent regulatory agencies worldwide (Wallsten, 2001a), although it took a couple of decades before other countries followed competition in their telecommunications market.

The debate for worldwide agreements on liberalization of the basic and enhanced telecommunications services took place under auspices of the World Trade Organization (WTO). Particularly, the General Agreement on Trade in Services (GATS) was concerned with these negotiations. The importance of trade agreements in services was recognized in 
1986, when the Ministerial Declaration on the Uruguay Round was made public. In 1994, the

General Agreement on Trade in Services was formed, in which all members agreed to

liberalize their telecommunications industry (McLarty, 1998) ${ }^{2}$. The General Agreement on

Trade in Services (GATS) was developed next to many other agreements on the deregulation

of the industry, such as the EU Liberalization Directives. In many countries, governments

allowed one competitor at first in a restricted setting, and later on introduced open

competition. They also reduced gradually their stake in their telecommunications companies

after the liberalization (Wallsten, 2001b). Furthermore, an independent regulatory agency

was created to protect fair competition and equal opportunities for all companies in the

telecommunications market. It was responsible for the adherence of telecommunications

companies to competition rules.

\section{Telecommunications Industry and the Open Markets}

In the last three decades, the environment in which the telecommunications industry was operating started to change. As globalization set the stage, the telecommunications industry became gradually a more global industry with increasing competition. In addition, new technological developments such as mobile telecommunications and digitalization have had a significant impact on the restructuring of the industry. Consequently, governments have started to privatize their state-owned telecommunications companies to open competition and to establish independent regulatory agencies. As mentioned above, the pace of liberalization,

\footnotetext{
2 Three goals were apparent in forming an agreement in the telecommunications sector: nondiscrimination among all members, market access, and, transparency of laws and regulations (McLarty, 1998). Nondiscrimination among all member countries basically means the allowance of foreign competition in the member countries' home market without any discriminatory favors to domestic service providers. The market access commitment takes this requirement too a higher level, and requires countries in all circumstances to allow the most liberal access too foreign providers in their home countries. This means releasing all tariff and non-tariff barriers. Furthermore, the member countries were required to employ the Schedule of Commitments in 1998. This schedule consists of an adherence to the General Obligations, the Specific Commitments, and the Reference Paper. The Specific Commitments, such as national treatment and market access, pertain only to the service sectors embraced by the Member countries. The Reference Paper consists of additional commitments of a Member country (McLarty, 1998).
} 
deregulation, and privatization however differed between regions. The next sections describe these differences.

\subsection{North America}

In 1984, the U.S. Justice Department's Consent Decree declared the divestiture of AT\&T's operating companies into seven Regional Bell Operating Companies (RBOCs), the Baby Bells. These RBOCs became providers of local telecommunications services and related telecommunications equipment (Kashlak \& Joshi, 1994). Their regional character was evident from the names the RBOCs had, like BellSouth or Southwestern Bell. AT\&T was left with its long distance telephony, network, equipment subsidiary and the Bell labs (Snow, 1995). The advantage of the new situation for AT\&T was the fact that they were now allowed to enter the information services market (Kennedy, 1989). Although the split up of AT\&T was an important step in the liberalization process of the industry, the RBOCs were still government regulated. This was partly due to their legacy of a monopolistic position in their core business. This competitive advantage had been balanced with restrictions in order to ensure a competitive market. For example, they were not allowed to enter the information services market. Even though RBOCs had similar starting points, over time, they developed their own strategy and competitive position (Kashlak \& Joshi, 1994). This development was affected by diverging regional regulatory strains and core business growth. Technology has further stimulated the dynamics of the industry. Particularly, the mobile telecommunications development has changed the environment substantially. The mobile telephony industry in the USA was launched in 1984 and grew enormously since 1988. Wireless communications was first adapted in the professional business and later by the consumer market. (Manova, Brody, Madhavapeddy \& Gylys, 1998).

\subsection{Europe}


The European mercantilist state monopolies faced a completely new situation in the liberalization era. In 1985, the 'Liberalization Directives' under Article 90 of the Treaty of Rome launched the deregulation of telecommunications market in the European Union. The European Union decided to create an open and competitive telecommunications market (Watson \& Wheadon, 1999). The consequential re-regulation of the industry was formulated in the 'Harmonization Directives' under Article 100a of the Treaty of Rome (Watson \& Wheadon, 1999). However, the Directives did not stress the pace of harmonization in the European Union. Consequently, countries have implemented these directives into their existing structures in a different way and pace. However, the creation of an open market has actually started after the acceptation of the Full Competition Directive in 1996. This Directive required all member states to have a completely liberalized telecommunications market in 1998. Table 1 presents an overview of the dates on which the European member states privatized and liberalized their telecommunications market.

---Insert table 1 about here---

Most EU countries have fully liberalized their telecommunications industry in 1998. Still, the table also shows that not all countries have fully privatized their telecommunications incumbent. Switzerland and Greece are some of the countries that have not fully privatized their telecommunications market yet. The United Kingdom (UK), on the other hand, was the first EU member state that privatized and liberalized its telecommunications industry. The acceptance of the 1984 Telecommunication Act has started the liberalization process of the industry in the UK (Thimm, 1992). Nonetheless, the UK gradually liberalized its telecommunications structure starting from a monopoly to a duopoly to partial liberalization and then full liberalization over a time span of 12 years. Regulation during this period was tight. For instance, the duopolists, Mercury and British Telecom (BT), both were subject to 
regulation to 'level the playing field', like interconnection price regulation, and a broadcastentertainment-services entry restriction. But also asymmetric regulation was present, like retail price caps (BT only), and network development restrictions (Mercury only). All restrictions were administered by OFTEL, the independent regulatory agency for the UK (Cave \& Williamson, 1996). In 1996, full liberalization set in, and OFTEL repositioned itself as a body concerned with competition issues, instead of a regulatory institution. It concentrated on eradication of anti-competitive behavior (Cave \& Williamson, 1996).

EU community policies were needed to guide the liberalization and standardization of the industry. The community policies were formed for the so-called radio spectrum. The radio spectrum consists of mobile and satellite communications, broadcasting, transport and R\&D. These community policies were translated into regulations and downwards communicated by the European Conference of Telecommunications administrations (CEPT) to independent regulatory authorities, like OFTEL, and the community (Economic Commission, 1998, p. 14) $)^{3}$.

The changes in the telecommunications environment of Eastern European countries were relatively similar to Western European countries. Their telecommunications industry showed comparable developments as in the Western European countries, although on a more gradual level. Next to the introduction of competition, the CEE countries also needed to modernize telecommunications services and develop a network (Holcer, 1995). Currently, most former state-owned telecommunications companies in Eastern Europe and the Baltic States are owned by foreign companies, in particular Western European telecommunications companies (Telcap, 2005).

\footnotetext{
${ }^{3}$ This section reports issues discussed in a green paper. Green papers are studies that give recommendations and are a basis for debate on the subject, whereas White papers contain the directives for realization of certain policies in the European Union (Thimm, 1992). Green papers give an accurate description of what is relevant in the discussion about this industry, which objectives the European Committee embraces as imperative for this business, and the European governments sincerely draw on the suggestions.
} 


\subsection{Asia and Pacific Region}

The GATS at the Uruguay Round also forced the Asian governments to liberalize their telecommunications industry, although the Asian region generally lagged behind in starting this course of action in comparison with Europe or North America. When competition was introduced in Asia, it happened only partially for certain regions or certain services (Fink, Mattoo \& Rathindran, 2003). Unrestricted entry, limitless private and foreign ownership, and independent regulatory bodies are still far away from realization of the agreements. (Fink et al., 2001). Table 2 presents the privatization policy of the fixed-line monopolies, considering local, long-distance and international services; and the presence of mobile operators in 17 Asian countries in the period 1989-1999.

---Insert table 2 about here---

Table 2 illustrates the mixture of methods used in telecommunications reform. Countries, like Bangladesh, Cambodia, Thailand and Vietnam showed limited or no privatization efforts. In China, India and South-Korea a few privatization barriers were removed. They maintained the position of the incumbent as a fully state-owned company while allowing some competition in certain fixed-line divisions. A more liberal situation was observed in, for example, Japan, Hong Kong, Indonesia, Pakistan and Singapore. However, this group of countries has also kept their competition restricted to particular areas and time periods. For instance, Japan opened parts of its telecommunications market in 1985. The new entrants were allowed in all markets, except for the local communications networks. However, also the latter was gradually liberalized over time (Omura, 1997; Tanaka, 1997). Furthermore, foreign ownership of the telecommunications companies was not allowed or limited (Fink et al., 2001). For instance, in the first years of deregulation in Japan, foreign ownership was restricted to one-third (Omura, 1997). In general, governments in Asia 
believed that especially the local providers generated the highest pay-offs and contributed most to the economic and social development of their country. A key industry as the telecommunications industry should therefore be fully controlled by the government or fully domestically owned. When foreign competition was allowed it was in the form of equity joint ventures to increase the knowledge of local companies.

The regulation in the mobile services was more relaxed, although the number of licenses, and thus the number of operators, was limited to a few, except for India, that registered 20 mobile operators in 1999. The mobile services were comparatively young and were not publicly owned in most countries. In the last years, these services showed tremendous growth and in some Asian countries the number of mobile subscribers even passed the number of fixed-line subscribers (Fink et al., 2001).

Australia and New Zealand also liberalized their telecommunications markets gradually. In Australia when competition was introduced, Telstra, the former state-owned monopolist, was under tight control concerning its prices, through price caps and tariff requirements. In New Zealand, the control on prices and interconnection was less stringent. Australia regulated the possibility of interconnection for Optus, and New Zealand simply encouraged Telecom, the former state-owned monopolist, to allow Clear on the local access network (Green \& Teece, 1998). In both countries, the mobile telecommunications industry was less constrained with regulation. As a result, the mobile telecommunications industry showed an explosive growth in competition (Green \& Teece, 1998).

\section{Telecommunications Industry and the Technological Developments}

In recent years, the telecommunications industry has evolved from manufacturing and providing basic fixed line telephony to an industry that offers mobile telecommunications services, and integrates IT and media into its services (Bourreau \& Doğan, 2001). In particular, mobile telecommunications innovation and digitalization have substantially 
changed the telecommunications landscape. The mobile telecommunications innovation has offered new forms of communications and services such as analog/digital cellular services, cordless telephony, trunking, and paging services (Krogt, 1996) ${ }^{4}$. Particularly the use of mobile services has dramatically grown in the last decade. According to the International Telecommunication Union (ITU) (2002c), the total number of mobile subscribers in the world increased from approximately 145 million to 1405 million respectively over the period $1996-2003^{5}$. However, the total number of fixed line subscribers in the world increased only from 738 million to 1143 million over the same period. Hence, the total number of subscribers for mobile services exceeded the total number of subscribers for fixed services in 2002 (ITU, 2002b). Figure 1 presents the development of the number of subscribers in fixed line and mobile services. The evidence shows the tremendous increase of mobile services starting at the end of the 1990s.

---Insert figure 1 about here---

The other main development that has had a significant impact on the landscape was the digitalization. Since the digital technological development, a convergence between the telecommunications industry and the information technology industry is observed. The digitalization of the telecommunications industry is the direct effect of the rapid expansion of Internet. The number of users globally rose from 20 million in 1996 to 400 million in 2000 (ITU, 2002b). The convergence of industries or digitalization of the telecommunications

\footnotetext{
${ }_{5}^{4}$ Cellular telephony takes up the largest part of mobile services.

${ }^{5}$ The International Telecommunication Union (ITU) is responsible for the development and standardization of telecommunication services in Western countries. Furthermore, it also stimulates and supports the construction of telecommunication networks and services in Less Developed Countries. The International Telegraph Union was established May $17^{\text {th }}, 1865$. When the telephone came into commercial use, the International Telegraph Union got involved into this part of communications as well. In 1903, the preliminary forms of radio communications became a part of the union as well. The mixture of these two fields was the underlying cause for the official name change in 1934 of the International Telegraph Union into the International Telecommunications Union (ITU, 2002a). The ITU is an affiliation of the United Nations (UN) and 186 countries are member.
} 
industry is the interplay of four different areas: customer devices, networks, network devices and content/software (Chan-Olmsted \& Jamison, 2001). Customer devices are the apparatus to receive and communicate, like telephones and PCs. Networks are links that transfer information. Network devices are the tools that control and accumulate the information. Content/software denotes the applications people employ (Thimm, 1992).

An additional integration is observed between telecommunications and consumer electronics and mass media. Nowadays, telecommunications services can generally be classified into two categories: basic services and enhanced services (McLarty, 1998). Basic telecommunication services consist of all voice and non-voice services transmitted without processing. Enhanced telecommunications services include specialized voice and non-voice services, requiring information processing, which adds value. The information transferred from one point to the other needs restructuring or a format change during this process. An example of enhanced services is the features on a mobile phone. Nowadays, mobile phones include the ability to make photos, tape a short video, or listen to the radio and mass media can deliver their content via satellite and telephony (Chan-Olmsted \& Jamison, 2001). When integrating the four areas, telephone, mass media, consumer electronics and computing, a new industry has developed, called the multimedia information industry (Fransman, 1997; Chan-Olmsted \& Jamison, 2001).

Another recent development in the telecommunications industry is the emergence of the so-called value network. Aggressive competition by new entrants of different industries in the New Economy have forced incumbent telecommunications companies to reconfigure their strategy and business. In this context, a new development is the value network. In a value network, companies from different industries jointly offer products to customers (Li \& Whalley, 2002). These value networks are made up of firms from the traditional economy but also from the New Economy. The value network is comprised of six areas: equipment and software, network, connectivity, navigation and middleware, applications and consumers (Li 
\& Whalley, 2002). Related to the value network is the concept of one-stop-shopping. Within one-stop-shopping, customers prefer only one incumbent to maintain all links leased through the network (Graack, 1996). Here, all services needed by the consumer should operate as if they belong to the same overarching network. Companies are, therefore, forced to engage in a search process for additional activities in an attempt to improve their 'fit' with these new business requirements. Especially, incumbent telecommunications companies are offering one-stop-shopping (Li \& Whalley, 2002). For example, BT acquired Tymnet, a network systems company, in order to provide customers with one-stop-shopping. Through this acquisition, BT is able to offer customers a portfolio of products in global data networks.

\section{Strategic Behavior of Telecommunications Companies}

Due to deregulation, technological innovation and the convergence of industries the telecommunications landscape has changed into a turbulent environment. The telecommunications companies had to make adequate adaptations to these changes and responded quickly to improve or to sustain their competitive advantage (Jamison, 1998; Hamel \& Prahalad, 1996; Chakravarthy, 1997). They have used several vehicles to adapt to the new requirements and to improve their long-term performance (Chakrabarti, Hauschildt \& Sueverkruep, 1994; Hitt, Hoskisson, Johnson \& Moesel, 1996; Williamson, 1996). The choice for a telecommunications company may range from a 'simple' non-equity agreement to a partial or even full equity transaction such as a joint venture, acquisition or merger. A non-equity agreement is any contractual agreement between two or more companies in which none of the companies have a degree of ownership. It is generally believed that this type of alliance has a relative short-term focus. An alliance with a more long-term focus is the joint venture. It is a joint effort to achieve interests through the formation of a new entity by two or more business partners. The new entity can have different ownership structures; however, in 
most cases the equity is distributed equally among the partners. Chan-Olmsted and Jamison (2001) researched the forms of alliances undertaken by telecommunication companies worldwide. They found that partnerships have frequently been used in the telecommunications industry, especially in the 1990s and they anticipated this trend to continue for the following reasons: globalization, economies of scale, competition, and, integrated product needs of the consumer. Technological advancement also is an important motive for the formation of alliances. Figure 2 shows the development of the number of partnerships by the telecommunications companies in the world since 1985 . The number of alliances has increased dramatically in the 1990s.

----Insert figure 2 about here----

However, a telecommunications company can use not only partnerships, it can also choose to acquire the operating assets of another company in exchange for either, cash, securities, or a combination of both (Capron \& Mitchell, 1998). It can acquire a minority stake (acquisition of less than 50\% equity) in another company or a majority stake (acquisition of more than $50 \%$ equity) in the company. The latter form provides the acquirer with an absolute controlling stake in the company. This means that the acquiring company will have a certain degree of authority over what happens in the telecommunications company. In an acquisition, the acquiring firm assumes the assets and liabilities of the acquired company (Gaughan, 1991). In the case of an acquisition the acquiring company continues to exist, whereas a merger is a combination of two or more firms in which a new firm is created. A merger joins resources of the separate entities in order to reach common goals. Figure 3 shows the development of the number of mergers and acquisitions (M\&As) in the telecommunications industry from 1985 to 2000 . The number of M\&As also increased dramatically in the 1990s. 
Given the globalization and the liberalization of telecommunications industry, many incumbents were forced to develop international strategies (Oh, 1996). Through international strategies, companies were able not only to enter foreign markets, but also to seek foreign assets (both of a tangible and an intangible nature) and to build $R \& D$, supply and production facilities abroad. External strategic options such as an acquisition or a partnership with a local company from the traditional or New Economy provide an established market position, access to existing infrastructure, and contact with local expertise. For example, KPN acquired Pantel, a Polish fixed-lines telecommunications company, the Belgian mobile operator BASE, and has a majority stake in E-Plus, a German mobile operator. Also, these strategic forms give companies access to a range of capabilities that they need to further develop both core activities and complementary activities. For example, BT acquired the U.S. network systems company Tymnet, the Spanish network services firm Banco Santander, and acquired several stakes in telecommunications companies in the Asia-Pacific region. Of course, firms could also enter foreign markets by setting up wholly owned subsidiaries. As foreign markets might be difficult to penetrate because lack of market presence and lack of information on customers' needs, local operating conditions and government regulations, companies generally prefer partnerships and M\&As. Figures 2 and 3 show the gradually increasing importance of telecommunications companies to ally with international partners and to become involved in cross-border M\&As. During the final years of the 1990s, the international focus increased exponentially. In general, the telecommunications industry has become more internationalized in the last decade.

Furthermore, technological developments have also created new opportunities and threats for incumbents (Chacko \& Mitchell, 1998; Kranenburg, Cloodt \& Hagedoorn, 2001). Previously distinct industries have converged and new substitutes and complementary 
products and services have been introduced in the market. To maintain their competitive position, telecommunications companies gained access to new and complementary capabilities, resources and businesses. The companies allied with companies from other industries and acquired companies in expanding and potential markets because of possible increased production, stronger market presence, greater control over industry direction and decreasing competitive pressure (Jamison, 1998). Due to new competitors from the New Economy, speed is becoming increasingly important for telecommunications companies to sustain or improve their position in the market (Carey, 2000). Particularly, inter-firm partnerships can play an important role in an industry where learning and flexibility form the basis of competition (Dussauge \& Garrette, 1999; Gomes-Casseres, 1996; Duysters \& Hagedoorn, 1999). Partnerships in the telecommunications industry are particularly suited to monitor new opportunities and markets at relatively low cost. They are a more flexible and less expensive mode to set up. Consequently, partnering between firms from different industries is expected to have increased during the last decade. For example, Telefonica has a partnership with California Micro Devices, has an equity stake in the provider of software and computer consulting services INFONET, a strategic alliance with IBM involved in information technology, and an equity stake in the producer of audiovisual content Patagonik Film group. Figure 2 presents the development of the number of alliances made by companies in the telecommunications industry from 1985 to 2000 . The minority of partnerships was focused on the telecommunications industry as such ${ }^{6}$. During the final years of the 1990s, the growth of this group of partnerships was lower than the growth of alliances with partners from other industries. Figure 3 also shows the same pattern for M\&As. For the 1990s the share of M\&As of firms from outside the telecommunications industry was higher than the share of within the industry M\&As. The second half of the 1990s marked a sudden increase in the share of M\&As of companies from other industries.

\footnotetext{
${ }^{6}$ Based on the two digit SIC-code 48 a distinction was made between telecommunications activities and non telecommunications activities.
} 


\section{$7 \quad$ Conclusions}

The telecommunications industry has been through some mayor developments in its lifetime. It started out with a mixture of privately owned and state-owned companies throughout the world. In the first half of the $20^{\text {th }}$ century, the telecommunications industry turned into a relative stable industry, which was completely government-owned. During the last decades, due to the liberalization and the privatization wave in the world, the telecommunications industry has rapidly changed. In the 1990s, the New Economy emerged and created new market opportunities for telecommunications firms. This study showed that many countries experienced a gradual process of liberalization with the goal of full liberalization. When competition was allowed in the industry, the trend was to first allow one vertically-integrated competitor into the market to create a player of similar strength with comparable resources as the previous monopolist had. The succeeding phase was one of more open competition. However, liberalization and privatization not only turned around the outlook of the telecommunications market but also the speed and extent of technological developments. Due to innovations, the telecommunications industry, together with other industries, is rapidly transforming into a new industry, the so-called multimedia-information industry. The industry is the focal industry in the third generation of leading industries (Thimm, 1992).

Deregulation, globalization, the emergence of the New Economy and introduction of new technologies such as mobile phones and broadband have forced the telecommunications companies to reconsider their strategy, their technological base and their product portfolio. In that context, companies have tried to develop and gain access to desired capabilities and resources and expanded across national boundaries to sustain their competitive advantages. Companies that lack some of the necessary new competencies used mergers, acquisitions, and partnerships with other companies to acquire the essential technological knowledge and to 
penetrate new markets. During the 1990s, the telecommunications companies were major acquirers of other companies and interesting partners for alliances.

This study also presented a general overview of major trends in inter-firm partnerships and M\&As in the telecommunications industry since 1985, examining both the general developments and the distribution according to internationalization and industries. The overall trends demonstrated an increase in importance of inter-firm partnerships and M\&As. The number of domestic inter-firm partnerships and M\&As as well as the international inter-firm partnerships and cross border M\&As showed an increasing pattern. Another interesting pattern was the increase in importance of other industries. In relative terms, the growth of alliances with partners outside the telecommunications industry superseded the increase in the number of alliances within the industry. M\&As demonstrated the same pattern as the inter-firm partnerships. An explanation for this specific pattern can be found in the companies' need for new capabilities and resources emerging from the New Economy, to compete in an industry that is transforming into a multimedia information industry. 


\section{References}

Andersson-Skog, L. (2000). National patterns in the regulation of railways and telephony in the Nordic countries to 1950, Scandinavian Economic History Review 48(2):30-46.

Bourreau, M. \& Doğan, P. (2001). Regulation and innovation in the telecommunications industry, Telecommunications Policy 25:167-184.

Capron, L. \& Mitchell, W. (1998). The role of acquisitions in reshaping business capabilities in the international telecommunications industry, Industrial and Corporate Change 7(4):715730.

Carey, D. (2000). A CEO roundtable on making mergers succeed, Harvard Business Review May-June:145-154.

Casson, H.N. (1971). The history of the telephone. Hallandale, Florida: New World Book Manufacturing Co., Inc.

Cave, M. \& Williamson, P. (1996). Entry, competition, and regulation in UK telecommunications, Oxford Review of Economic Policy 21(4):100-121.

Chacko, M. \& Mitchell, W. (1998). Growth incentives to invest in a network externality environment, Industrial and Corporate Change 7(4):731-744.

Chakravarthy, B.S. (1991). Strategic adaptation to deregulation, Journal of Organizational Change Management 4(1):22-32.

Chakravarthy, B.S. (1997). A new strategy framework to coping with turbulence, Sloan Management Review 38(2):69-82.

Chakrabarti, A., Hauschildt, J. \& Sueverkruep, C. (1994). Does it pay to acquire technological firms?, R\&D Management 24:47-56.

Chandler, A.D., Jr. (2001). Scale and Scope: The dynamics of industrial capitalism. Cambridge, Massachusetts; London, England: The Belknap Press of Harvard University Press. 
Chan-Olmsted, S. \& Jamison, M. (2001). Rivalry through alliances: Competitive strategy in the global telecommunications market, European Management Journal 19(3):317-331.

Dussauge, P. \& Garrette, B. (1999). Cooperative strategy - competing successfully through strategic alliances. Chichester: Wiley.

Duysters, G. \& Hagedoorn, J. (1999). Technological Convergence in the IT Industry: The role of strategic technology alliances and technological competencies, International Journal of the Economics and Business 5:355-368.

Economic Commission (1998). Green paper on radio spectrum policy, COM(1998)596.

Fink, C., Mattoo, A. \& Rathindran, R. (2001). Liberalizing basic telecommunications: The Asian experience, working paper, Development Research Group, World Bank.

Fink, C., Mattoo, A. \& Rathindran, R. (2003). An assessment of Telecommunications Reform in Developing Countries, Information Economics and Policy 15:443-466.

Fransman, M. (1997). Towards a new agenda for Japanese telecommunications, Telecommunications Policy 21(2):185-194.

Gaughan, P.A. (1991). Mergers and acquisitions. New York: HarperCollins.

Gomes-Casseres, B. (1996). The alliance revolution: The new shape of business rivalry. Cambridge: Harvard University Press.

Graack, C. (1996). Telecom operators in the European Union: Internationalization strategies and network alliances, Telecommunications Policy 20(5):341-355.

Green, J.R. \& Teece, D.J. (1998). Four approaches to telecommunications deregulation and competition: The USA, the UK, Australia and New Zealand, Industrial and Corporate Change 7(4):623-635.

Hamel, G. \& Prahalad, C.K. (1996). Competing in the new economy: Managing out of the bounds, Strategic Management Journal 17:237-242.

Hitt, M.A., Hoskisson, R.E., Johnson, R.A. \& Moesel, D.D. (1996). The market for corporate control and firm innovation, Academy of Management Journal 39:1084-1119. 
Holcer, N. (1995). The changing telecommunications environment in CEE. In Lamberton, D.M. (Ed.), Beyond competition: The future of telecommunications, 279-298. Amsterdam: Elsevier.

ITU (2002a). ITU overview - history. Retrieved 18-12-03 from the World Wide Web: http://www.itu.int/aboutitu/overview

ITU (2002b). World Telecommunication Development Conference (WTDC-02), Istanbul, Turkey. Note by the director of BDT, input for the drafting of the strategic plan of the development sector for the 2003-2006 period. Catalogue number: 2128-012-EN. ITU (2002c). ITU Free Statistics. Retrieved 21-03-05 from the World Wide Web: http://www.itu.int/ITU-D/ict/statistics/at_glance/_page.print Jamison, M.A. (1998). Emerging patterns in global telecommunications alliances and mergers, Industrial and Corporate Change 7(4):695-713.

Kashlak, R.J. \& Joshi, M.P. (1994). Core business regulation and dual diversification patterns in the telecommunications industry, Strategic Management Journal 15:603-611.

Kennedy, C. (1989). The transformation of AT\&T, Long Range Planning 22(3):10-17. Kranenburg, H.L. van, Cloodt, M. \& Hagedoorn, J. (2001). An exploratory study of recent trends in the diversification of Dutch publishing companies in the multimedia and information industries, International Studies of Management and Organization 31(1):64-86. Krogt, A.W. van der (1996). Service development in less developed countries: The case of telecom services in Chile and Argentina. Doctoral thesis. Amsterdam: Thesis Publishers. Li, F. \& Whalley, J. (2002). Deconstruction of the telecommunications industry: from value chains to value networks, Telecommunications Policy 26:451-472.

Manova, S., Brody, G., Madhavapeddy, S. \& Gylys, V. (1998). Mass market entry of wireless telecommunications, Industrial and Corporate Change 7(4):679-693. McLarty, T.L. (1998). Liberalized telecommunications trade in the WTO: Implications for universal service policy, Federal Communications Law Journal 51(1):1-59. 
Oh, J. (1996). Global strategic alliances in the telecommunications industry,

Telecommunications Policy 20(9):713-720.

Omura, T. (1997). Japan's stumbling policy for competition in the telecommunications industry, Telecommunications Policy 21(2):127-141.

Snow, M.S. (1995). The AT\&T divestiture: A 10-year retrospective. In Lamberton, D.M. (Ed.), Beyond competition: The future of telecommunications, 279-298. Amsterdam: Elsevier.

Stubbs, C. (2004). Partnering in the new economy, European Business Journal 113-119. Tanaka, E. (1997). The status of Nippon Telegraph and Telephone Corporation (NTT), Telecommunications Policy 21(2):85-99.

Telcap (2005). Incumbents on the acquisition trail, January 2005. Retrieved 21-02-05 from the World Wide Web: http://www.telcap.co.uk/news/?id=184.

Thimm, A.L. (1992). America's stake in European telecommunication policies. Westport, Connecticut; London: Quorom books.

Wallsten, S.J. (2001a). Ringing in the $20^{\text {th }}$ century: The effects of state monopolies, private ownership, and operating licenses on telecommunications in Europe, 1892-1914, Working Paper, World Bank Research: no. 2690.

Wallsten, S.J. (2001b). An econometric analysis of telecom competition, privatization, and regulation in Africa and Latin America, The Journal of Industrial Economics XLIX(1):1-19. Watson, C. \& Wheadon, T. (1999). Telecommunications: The EU law. Simmons \& Simmons, Bembridge, UK: Palladian Law Publishing Ltd.

Waverman, L. \& Trillas, F. (2002). Corporate control and industry structure in global communications: An introduction, Editorial, Telecommunications Policy, 26:219-224. Williamson, O.E. (1996). The mechanisms of governance. Oxford: Oxford University Press. 
Table 1: Dates of privatization and liberalization in the European countries

\begin{tabular}{|c|c|c|c|}
\hline Year & Partial privatization & Complete privatization & Liberalization \\
\hline 1984 & $\begin{array}{l}\text { United Kingdom } \\
(52,4 \%)^{7}\end{array}$ & & \\
\hline 1987 & Spain $(66,8 \%)$ & & \\
\hline 1991 & United Kingdom $(78,2 \%)$ & & United Kingdom \\
\hline 1993 & & United Kingdom & Sweden \\
\hline 1994 & $\begin{array}{l}\text { Denmark } \\
\text { Netherlands }\end{array}$ & & \\
\hline 1995 & & & Finland \\
\hline 1996 & $\begin{array}{l}\text { Germany (26\%) } \\
\text { Portugal }(49 \%)\end{array}$ & & \\
\hline 1997 & $\begin{array}{l}\text { Austria } \\
\text { France } \\
\text { Italy }\end{array}$ & Spain & Denmark \\
\hline 1998 & $\begin{array}{l}\text { Switzerland }(49,99 \%) \\
\text { Finland }(22,2 \%)\end{array}$ & Denmark & $\begin{array}{l}\text { Austria } \\
\text { Belgium } \\
\text { France } \\
\text { Germany } \\
\text { Ireland } \\
\text { Italy } \\
\text { Netherlands } \\
\text { Norway } \\
\text { Spain } \\
\text { Switzerland }\end{array}$ \\
\hline 1999 & Finland $(42,4 \%)$ & & \\
\hline 2000 & $\begin{array}{l}\text { Austria }(55,6 \%) \\
\text { Finland }(47,2 \%) \\
\text { Norway }(22,3 \%) \\
\text { Sweden }\end{array}$ & Portugal & \\
\hline 2001 & & & Greece \\
\hline 2002 & $\begin{array}{l}\text { Belgium }(50 \%-1 \text { share }) \\
\text { Switzerland }(40 \%) \\
\text { Finland }(19,4 \%)^{8}\end{array}$ & Italy & \\
\hline 2004 & $\begin{array}{l}\text { Greece }(66,3 \%) \\
\text { Switzerland }(33,9 \%)\end{array}$ & & \\
\hline
\end{tabular}

Sources: Annual reports and websites of the formerly state-owned companies.

\footnotetext{
${ }^{7}(. \%)=$ percentage privatized
}

${ }^{8}$ In 2002, the Finnish state had a 19,4\% stake in TeliaSonera and the Swedish state had a stake of $46 \%$. 
Table 2: Stages of telecommunication reform policy in 17 Asian countries 1989-1999.

\begin{tabular}{|c|c|c|c|c|c|}
\hline \multirow[t]{2}{*}{ Country } & \multirow{2}{*}{$\begin{array}{l}\text { \% Privatization } \\
\text { state-owned } \\
\text { monopoly }\end{array}$} & \multicolumn{3}{|l|}{ Fixed-line services } & \multirow{2}{*}{$\begin{array}{l}\text { Number of } \\
\text { Mobile operators }\end{array}$} \\
\hline & & Local & Long-distance & International & \\
\hline Bangladesh & & $\begin{array}{l}\text { Monopoly, } \\
\text { Competition in } \\
\text { selected rural } \\
\text { areas }\end{array}$ & Monopoly & Monopoly & 1999: 4 \\
\hline Cambodia & & Monopoly & Monopoly & Monopoly & 1999: 4 \\
\hline China & $0 \%$ & Monopoly & 1997: Duopoly & Monopoly & $\begin{array}{l}\text { 1989: } 1 \\
\text { 1996: } 2\end{array}$ \\
\hline Hong Kong & & $\begin{array}{l}\text { 1999: Fixed } \\
\text { competition }\end{array}$ & n.a. & 1999: Competition & 1999: 6 \\
\hline India & $0 \%$ & $\begin{array}{l}\text { 1998: Regional } \\
\text { duopolies }\end{array}$ & 1999: Competition & Monopoly & $\begin{array}{l}\text { 1995: } 8 \\
\text { 1999: } 20\end{array}$ \\
\hline Indonesia & $\begin{array}{l}\text { 1995: } 19 \% \\
1997: 23 \%\end{array}$ & $\begin{array}{l}\text { 1999: Monopoly, } \\
\text { joint ventures in } \\
\text { selected areas }\end{array}$ & Monopoly & 1999: Duopoly & $\begin{array}{l}\text { 1989: } 1 \\
\text { 1996: } 7\end{array}$ \\
\hline Japan & & 1999: Competition & 1999: Competition & 1999: Competition & 1999: Competition \\
\hline Korea & $\begin{array}{l}\text { 1993: } 10 \% \\
1996: 29 \%\end{array}$ & Monopoly & 1996: Duopoly & $\begin{array}{l}\text { 1991: Fixed } \\
\text { competition }\end{array}$ & $\begin{array}{l}\text { 1989: } 1 \\
\text { 1997: } 5\end{array}$ \\
\hline Malaysia & 1990: $25 \%$ & $\begin{array}{l}\text { 1996: Fixed } \\
\text { competition }\end{array}$ & $\begin{array}{l}\text { 1996: Fixed } \\
\text { competition }\end{array}$ & $\begin{array}{l}\text { 1994: Fixed } \\
\text { competition }\end{array}$ & $\begin{array}{l}\text { 1989: } 2 \\
\text { 1997: } 8\end{array}$ \\
\hline Nepal & & Monopoly & Monopoly & Monopoly & n.a. \\
\hline Pakistan & 1994: $12 \%$ & Monopoly & Monopoly & Monopoly & $\begin{array}{l}\text { 1990: } 2 \\
\text { 1995: } 3\end{array}$ \\
\hline Philippines & 1989: $100 \%$ & $\begin{array}{l}\text { 1995: Fixed } \\
\text { competition }\end{array}$ & $\begin{array}{l}\text { 1995: Fixed } \\
\text { competition }\end{array}$ & $\begin{array}{l}\text { 1992: Fixed } \\
\text { competition }\end{array}$ & $\begin{array}{l}\text { 1991: } 2 \\
\text { 1994: } 5\end{array}$ \\
\hline Singapore & $\begin{array}{l}\text { 1993: } 11 \% \\
\text { 1996: } 17 \%\end{array}$ & 1999: Duopoly & Monopoly & 1999: Duopoly & $\begin{array}{l}\text { 1989: } 1 \\
\text { 1999: } 3\end{array}$ \\
\hline Sri Lanka & 1997: $34 \%$ & $\begin{array}{l}\text { 1996: Fixed } \\
\text { competition }\end{array}$ & $\begin{array}{l}\text { 1996: Fixed } \\
\text { competition }\end{array}$ & Monopoly & $\begin{array}{l}\text { 1989: } 1 \\
\text { 1995: } 4\end{array}$ \\
\hline Thailand & & Monopoly & Monopoly & Monopoly & 1999: 5 \\
\hline Taiwan-China & & 1999: Competition & 1999: Competition & 1999: Competition & 1999: 6 \\
\hline Vietnam & & Monopoly & Monopoly & Monopoly & 1999: 3 \\
\hline
\end{tabular}

Source: Fink, C., Mattoo, A. \& Rathindran, R. (2001). 
Figure 1: Development of total number of fixed telephone line and mobile cellular subscribers worldwide: period 1991-2003

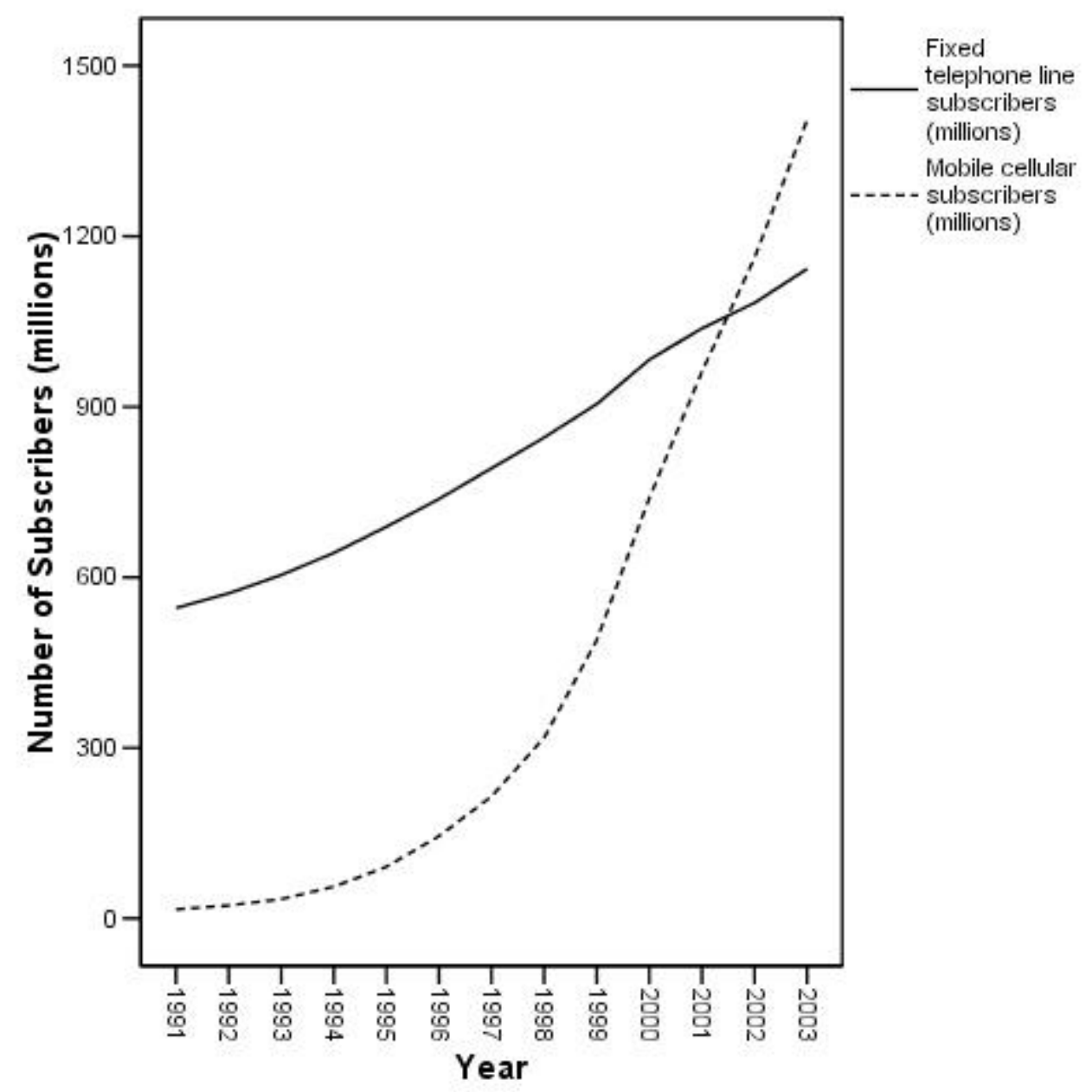

Source: ITU (2002c). 
Figure 2: Development of total number of alliances, total number of domestic alliances and total number of within the industry alliances in the telecommunications industry: period $1985-2000$

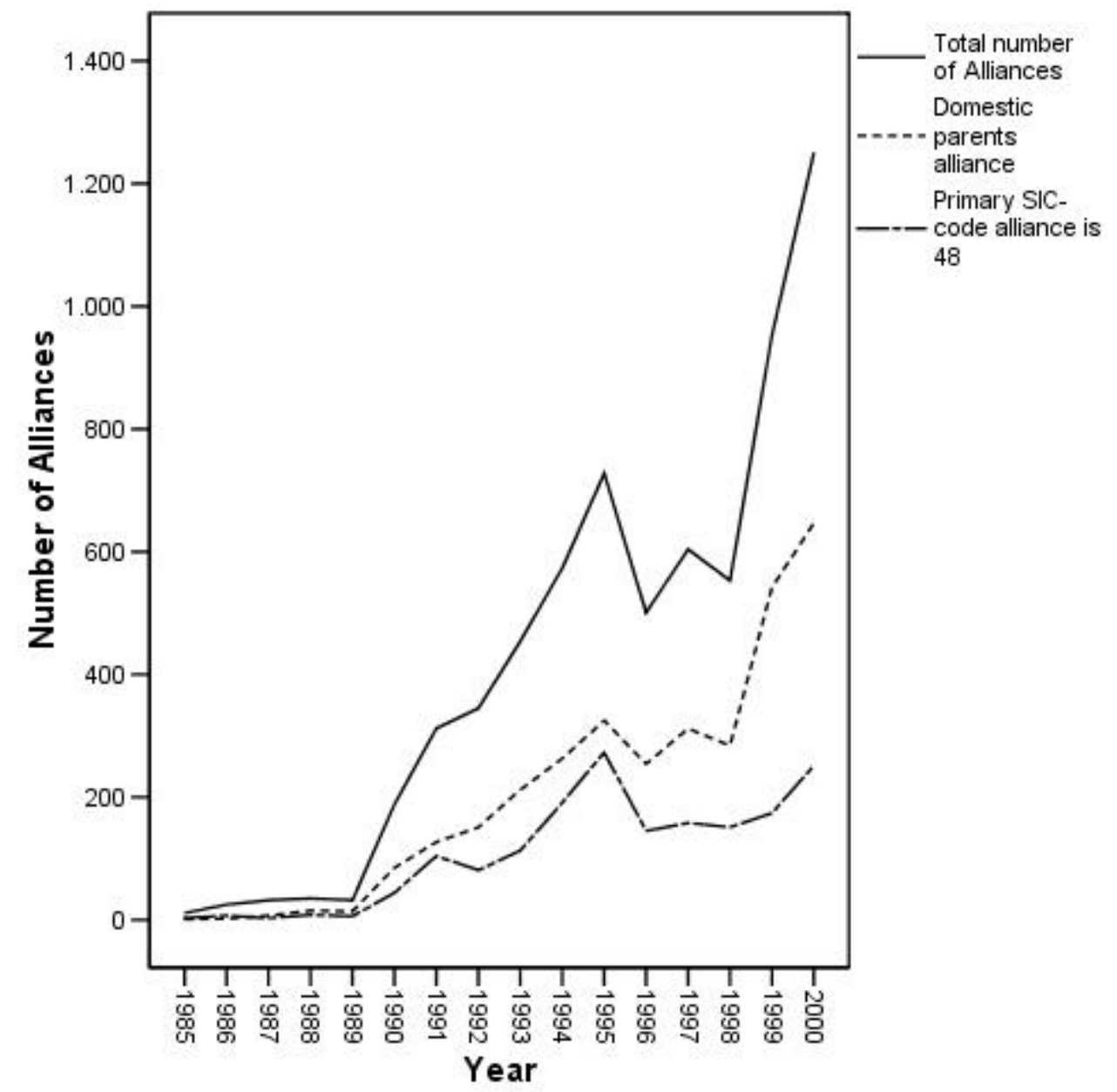

Source: Thomson Security Data (2003) 
Figure 3: Development of total number of M\&As, total number of cross-border M\&As and total number of within the industry M\&As in the telecommunications industry: period 19852000

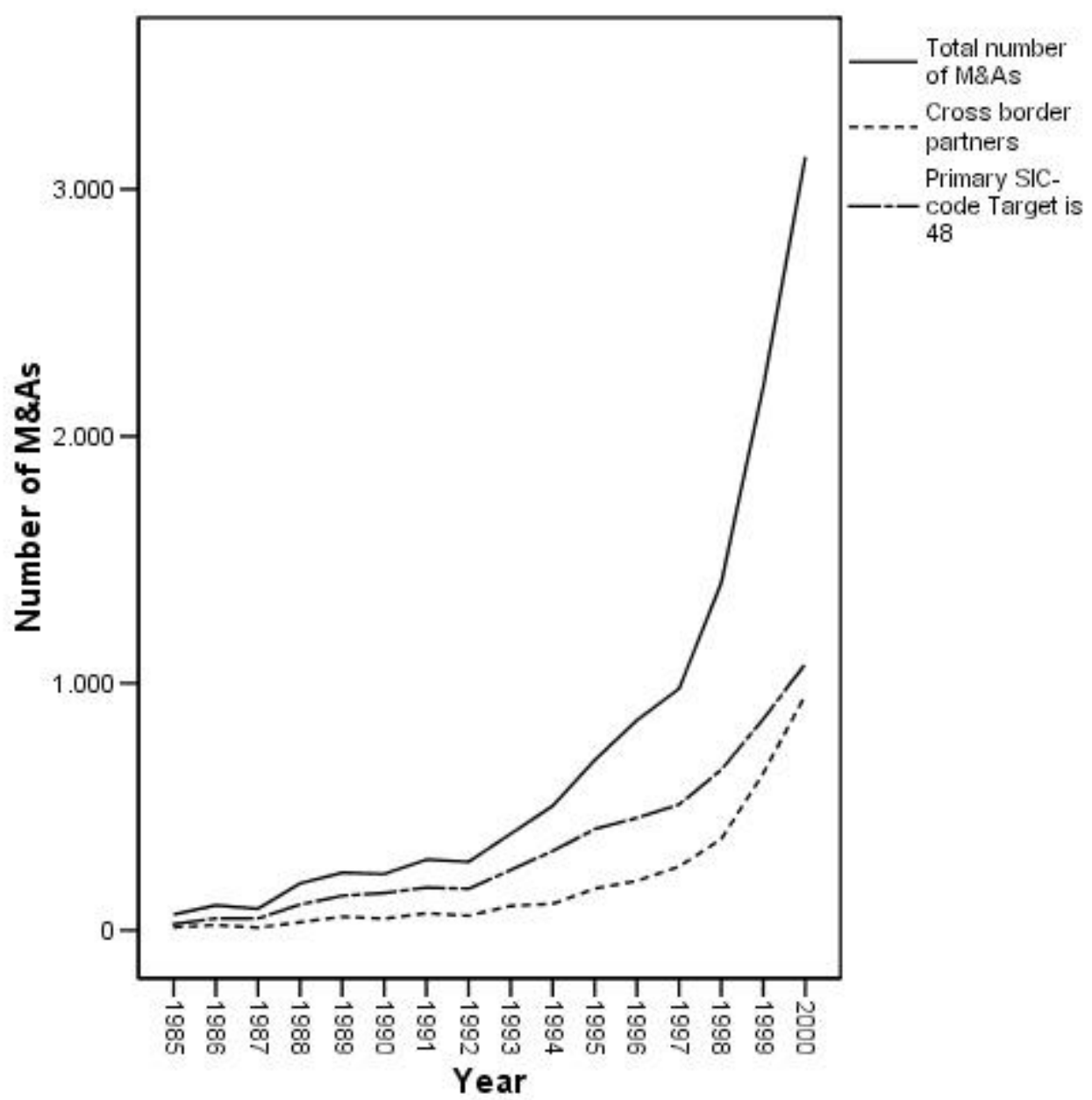

Source: Thomson Security Data (2003) 